\title{
Knowledge, Attitude and Practice Regarding Dengue Infection among Ipoh Community, Malaysia
}

\author{
Jannathul Firdous ${ }^{*}$, Ariza Mohamed, Muhammad Al Amin, Muhamad Ihsan, Muhammad Faris ‘Imadi, \\ Muhammad Khairul Hakim, Muhamad Afiq, Noorzaid Muhamad \\ Faculty of Medicine, Universiti Kuala Lumpur Royal College of Medicine Perak, No.3, Jalan Greentown, 30450, Ipoh, Perak, Mala ysia.
}

\begin{tabular}{ll} 
ARTICLE INFO & ABSTRACT \\
$\begin{array}{l}\text { Article history: } \\
\text { Received on: } 15 / 03 / 2017\end{array}$ & $\begin{array}{l}\text { Knowledge relating with dengue infection is the description about its infection, symptoms, vectors and its mode } \\
\text { of transmission whereas attitude against dengue infection is the mind-set of a person towards anything against } \\
\text { its infection. The effort and action of a person to prevent or reducing the spread of dengue infection is called as } \\
\text { practice. The objective of this study was to obtain data from the sample population on dengue related } \\
\text { knowledge, attitude and practice and to aided the knowledge, attitude and practice with socio-demographic } \\
\text { issues. The result of study showed that the community were alert on knowledge and practice about dengue. }\end{array}$ \\
\hline $\begin{array}{l}\text { Key words: } \\
\text { Attitude, Dengue, Education, } \\
\text { Infection, Knowledge, Virus } \\
\text { and Vector. }\end{array}$ & $\begin{array}{l}\text { However, there was a bit lack of attitude regarding dengue infection because the percentage of participants } \\
\text { whom were aware about the risk of getting infection by dengue was poor. More practical health education } \\
\text { programmes should therefore be organized to give more benefits and exposure which could increase the attitude } \\
\text { of the community regarding dengue infection. }\end{array}$ \\
\hline
\end{tabular}

\section{INTRODUCTION}

Dengue is an acute mosquito-borne viral infection that is rapidly spreading in tropical and subtropical countries. This infection is caused by arbovirus and transmitted by Aedes aegypti and Aedes Albopictus. When the viral infected mosquitoes bites human, he become a reservoir and more viruses become generated in the host by viral replication and they again become a viral source for mosquitoes. Dengue virus is a small singlestranded RNA virus with four serotypes DEN-1, DEN-2, DEN-3 and DEN-4. These serotypes belong to the genus flavivirus of flaviviridae family. Even after neutralization, antibody produced from the first infection causes more serious infection during secondary infections by other serotypes (Qadir et al., 2015). Types of these viral infection include dengue fever (DF) about ( $95 \%$ of cases), and a more severe cases cause dengue

\section{* Corresponding Author}

Jannathul Firdous, Faculty of Medicine, Universiti Kuala Lumpur Royal College of Medicine Perak, No.3, Jalan Greentown, 30450, Ipoh, Perak, Malaysia. Email: Jannathul.firdous @ unikl.edu.my haemorrhagic fever (DHF) or dengue shock syndrome (DSS-5\% of cases). Further, dengue infections are symbolized by frontal headache, retro-orbital pain, body aches, nausea and vomiting, joint pains, weakness and rash (Abd Kadir et al., 2013). Against its dangerous effects, currently there is no licensed and approved vaccine or antiviral available (Messina et al., 2014).

Majority of highly urbanized cities in the world were infected by this dengue which shows the ostensible burden of disease. This disease still endemic around 112 countries among the world and DHF rate was reported in greater than 60 of these countries. Even in developed country such as America, the incidence of dengue fever was said to be increased (Siqueira et al., 2004). When comparing by gender, DHF common in males was observed however, female gender showed higher mortality rate (Khan et al., 2007). Against its dangerous effects, till now, no determined antiviral treatment are available (Messina et al., 2014). In addition, knowledge, attitudes and practices (KAP) of the population regarding dengue fever is lacking among the population. Even to control vector in infected area, effective involvement of the local community is needed (Syed et al., 2010). 
KAP surveys are immediate and necessary at this moment to evaluate dengue control programs and also to establish active strategies for controlling the disease more effectively (Guha-Sapir and Schimmer, 2005). This study was therefore undertaken to analyse the level of knowledge, type of attitude and the type practices regarding dengue infection focused on the study population. This type of survey will be valuable for future dengue campaigns or programs within community as well as provide better consideration for what element is lacking in the community.

\section{MATERIALS AND METHODS}

\section{Study Design and population}

Cross sectional study design was aimed to provide data for the entire population under study. The study population included the population living in the area of Dewan Bandaraya Ipoh.

\section{Sample Population and sample size}

This research was conducted at Kampung Kepayang which falls under the jurisdiction of Dewan Bandaraya Ipoh. We were using the service of the website (www.openepi.com) to calculate the sample size. Out of 1,200 people, approximately 86 adults were involved in this study using the sample size formula.

\section{Data Collection}

Printed questionnaires were then given out to the respondents to be answered. Details given by the respondents were kept confidential and was not exposed to other parties unless the respondents himself wishes to do so. Data were collected using questionnaire which were self-administered by the respondents. In the questionnaire, there were questions regarding the knowledge, attitude and practices of respondents towards dengue infections. Data was entered and analysed under the categorical analysis.

\section{RESULTS AND DISCUSSION}

A total of 86 participants volunteered to answer the study questionnaires during the study period. Majority of the respondents are male $(54.7 \%)$. Majority of the respondents are above 51 years old (41.9\%), the others are 20-35 (34.9\%) and 3650 years old $(23.3 \%)$. All respondents are Malay (100\%) as shown in Table 1.

Table 1A: Frequency Table for Socio-demographic status showing Age, Gender and Ethnicity.

\begin{tabular}{lccccc}
\hline \multicolumn{2}{l}{ Age } & Frequency & Percent & $\begin{array}{c}\text { Valid } \\
\text { Percent }\end{array}$ & $\begin{array}{c}\text { Cumulative } \\
\text { Percent }\end{array}$ \\
\hline \multirow{4}{*}{ Valid } & $20-35$ & 30 & 34.9 & 34.9 & 34.9 \\
& $36-50$ & 20 & 23.3 & 23.3 & 58.1 \\
& $>51$ & 36 & 41.9 & 41.9 & 100.0 \\
& Total & 86 & 100.0 & 100.0 & \\
\hline
\end{tabular}

Among the participants, $1.2 \%$ has no proper education, $24.4 \%$ completed primary school, $59.3 \%$ completed secondary school and $15.1 \%$ completed college level of education. Of the total, $75.6 \%$ are urban poor, $18.5 \%$ are middle income class and $5.8 \%$ have high income. Data were collected with information based on knowledge, attitude and practice in relation with age, gender, education and total income of the family.

Table 1B: Frequency Table for Socio-demographic status showing Gender.

\begin{tabular}{cccccc}
\hline \multicolumn{2}{c}{ Gender } & Frequency & Percent & $\begin{array}{c}\text { Valid } \\
\text { Percent }\end{array}$ & $\begin{array}{c}\text { Cumulative } \\
\text { Percent }\end{array}$ \\
\hline Valid & male & 47 & 54.7 & 54.7 & 54.7 \\
& female & 39 & 45.3 & 45.3 & 100.0 \\
& Total & 86 & 100.0 & 100.0 & \\
\hline
\end{tabular}

Table 1C: Frequency Table for Socio-demographic status showing Ethnicity.

\begin{tabular}{|c|c|c|c|c|}
\hline Ethnicity & Frequency & Percent & $\begin{array}{l}\text { Valid } \\
\text { Percent }\end{array}$ & $\begin{array}{c}\text { Cumulative } \\
\text { Percent }\end{array}$ \\
\hline malay & 86 & 100.0 & 100.0 & 100.0 \\
\hline
\end{tabular}

\section{Knowledge}

Referring on the data, the age category $>51$ was the most abundant $(51.5 \%)$ in the low knowledge category while the age category 20-35 was the majority (45.2\%) in the high knowledge category. Based on the Pearson Chi-Square, the significant value was 0.446 . This indicate that there was less likely any relation between knowledge and age as shown in (Fig. 1A). In high knowledge and low knowledge category, the spread of male and female there was quite similar (Low; Male 18.6\%, Female $19.8 \%$, High; Male $19.8 \%$, Female $16.3 \%$ ). This was to indicate less likely relation regarding the knowledge and gender (Fig. 1B)
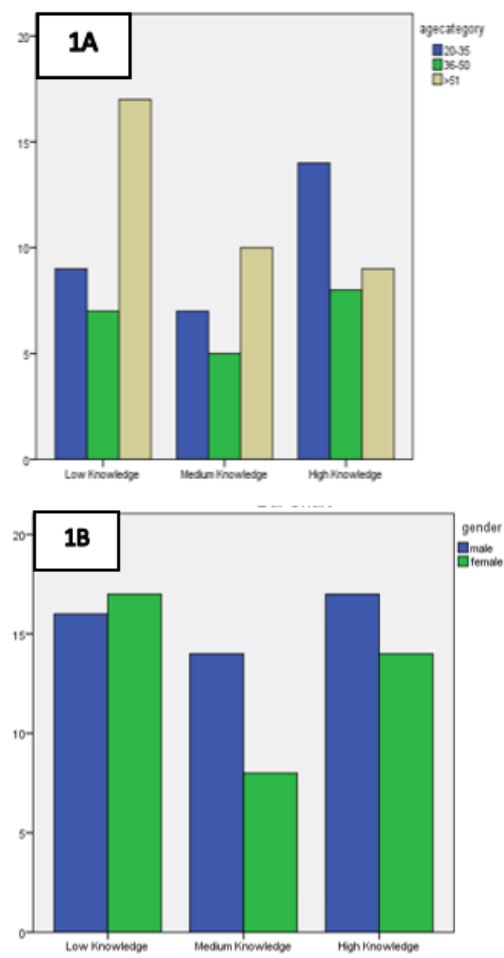

Fig. 1A: Total Knowledge against Age Category.

Fig 1B: Total Knowledge against Gender Category 
The participant with no prior education had low knowledge $(100 \%)$ regarding dengue infection. Participants with primary education were in low knowledge category $(52.4 \%)$, which indicates small relation between education level and knowledge (Fig. 1C). Participants who were urban poor spread majorly $(44.6 \%)$ in the Low knowledge category. This indicate there was small relation regarding income category and knowledge (Fig: 1D).
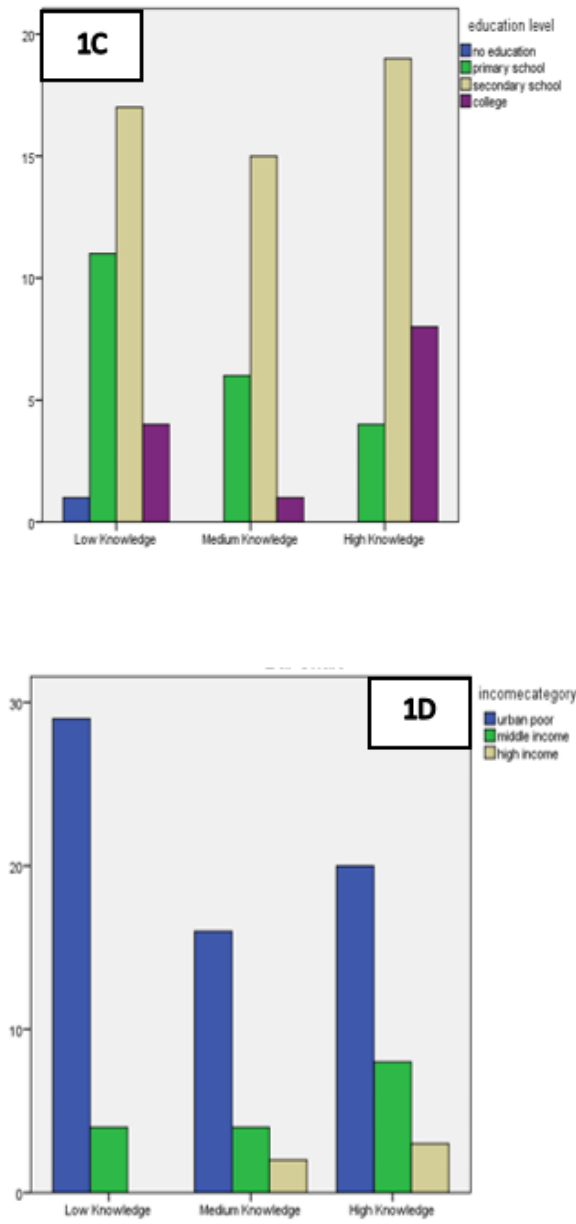

Fig 1C: Total Knowledge against Education Level Category, Fig 1D: Total Knowledge against Income Category.

We define Medium Knowledge and High Knowledge as good knowledge on dengue infection. The study showed that majority of the people $(61.6 \%)$ has good knowledge on dengue infection. When compared to the same study conducted on students from Alam Shah Science School by Balsam Mahdi Nasir Al-Zurfi et al. (2015), there was only a slight difference between the scores. The small difference was probably due to both studies being conducted in Malaysia. This indicates that the exposure of school students and the community towards dengue education were almost the same. Moreover, the people in Malaysia of all ages nowadays were used to technology where they can get information on dengue infection from the worldwide web and mass media. Not to mention, healthcare visits by the government to schools and communities. Based on our study, there was no significant relation between knowledge and sociodemographic factors.

\section{Attitude}

According to graph, majority of the medium attitude was aged 51 and above (45.7\%) followed by age 20-35 (40.0\%). There was a small significant relationship between attitude and age (Fig. 2A). Majority of medium attitude group were male (54.3\%). Also, majority of high attitude group were male $(54.9 \%)$. Based on Pearson Chi-Square, there was very little significant relationship between attitude and gender (Fig. 2B).
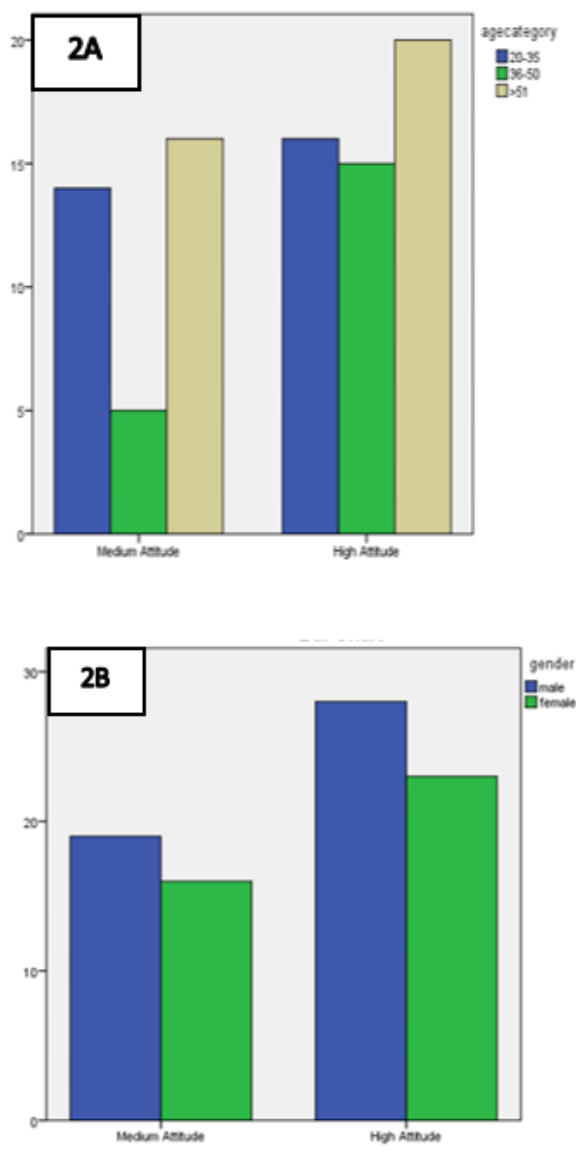

Fig 2A: Total Attitude against age Category,

Fig 2B: Total Attitude against Gender Category.

Majority of the medium attitude comes from people who completed secondary school (57.1\%). Second most was from respondents who educated from primary school (28.6\%), followed by people who completed college $(11.4 \%)$. There was small significant relationship between attitude and education level (Fig. 2C). When compare against income, urban poor respondents had major percentage in medium $(80.0 \%)$ and high attitude $(72.5 \%)$ group. Middle income group showed second most percentage in 
medium $(17.1 \%)$ and high attitude $(19.6 \%)$ group. Lastly, high income had the lowest percentage. There was small significant relationship between attitude and income (Fig. 2D).
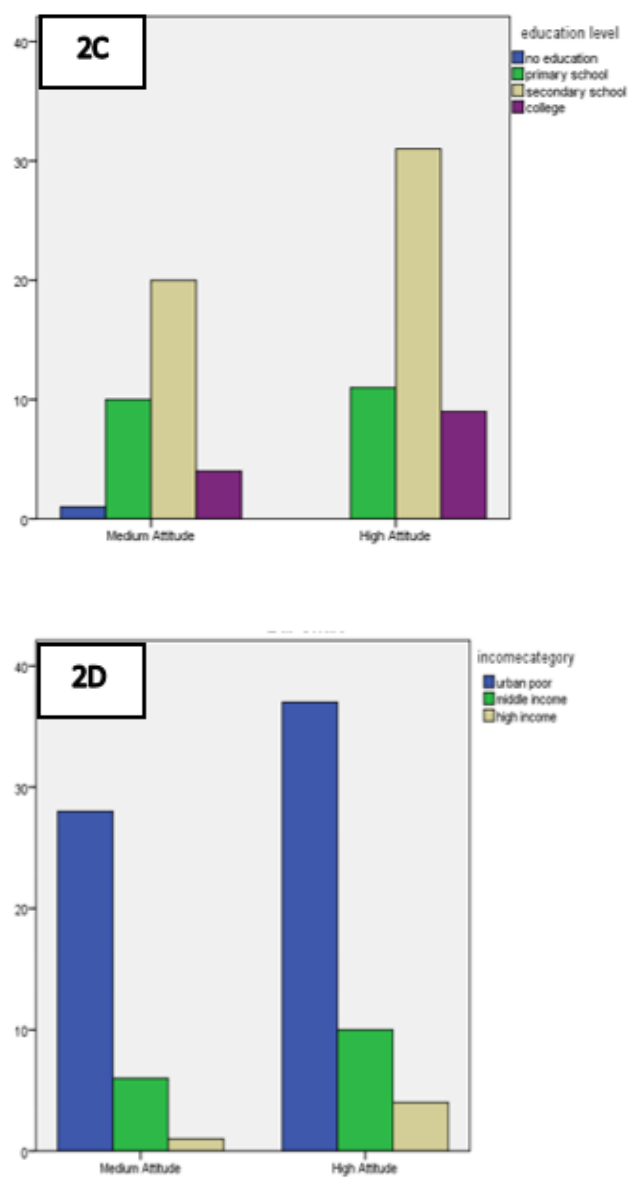

Fig 2C: Total Attitude against Education Level Category,

Fig 2D: Total Attitude against Income Category

We defined high attitude as good attitude in our research on knowledge, attitude and practice of dengue infection on Ipoh community. In our research that we conducted, we find out that the high attitude value was $59.3 \%$ while in the research that were conducted on the knowledge, attitude and practice of dengue fever and health education programme among students of Alam Shah Science School, Cheras, Malaysia by Balsam Mahdi Nasir AlZurfi et al. (2015), and value of high attitude is $80 \%$. This means that the Ipoh community have lack of attitude on dengue infection if compared to the students of Alam Shah Science School. The reason for this that they were immune to the dengue virus. Other than that, maybe they were trapped in a simple minded thinking that dengue is a simple disease that can be cured by a simple way(Koenraadt et al., 2006).

\section{Practices}

There was only 1 respondent who was in the age of 3650 years old $(100.0 \%)$ in the low practice while in the medium practice there were 4 persons in the range of 20-35 years old (66.7\%), 1 person in the range of $36-50$ years old $(16.7 \%)$ and 1 person in the range of more than 50 years old $(16.7 \%)$. In the High practice, there were 26 persons in the range of 20-35 years old $(32.9 \%), 18$ persons in the range of 36-50 years old (22.8\%) and 35 persons in the range of more than 50 years old (44.3\%) as shown in (Fig. 3A). There was only 1 male (100\%) in the low practice. In the medium practice, there was only 1 male $(16.7 \%)$ and 5 females $(83.3 \%)$ while in the high practice, there were 45 males $(57.0 \%)$ and 34 females (43.0\%) as shown in (Fig. 3B).
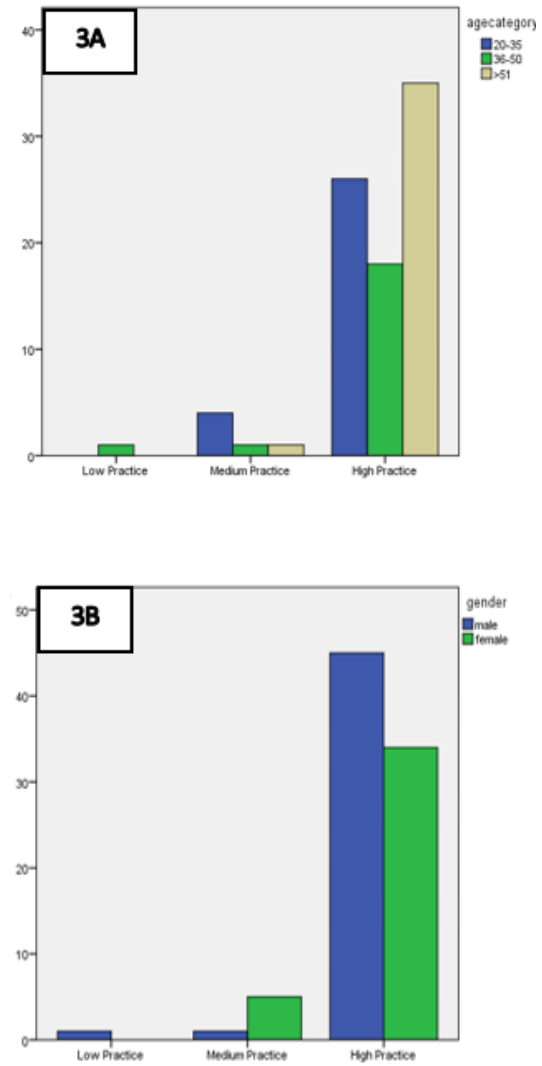

Fig 3A: Total Practice against age Category,

Fig 3B: Total Practice against Gender Category

Only one respondent from secondary education (100.0\%) falls under the low practice category. However, in the medium practice category, one respondent had no education (16.7\%), two respondents who went to primary school (33.3\%), two respondents who went to secondary school (33.3\%) and one respondent went to college $(16.7 \%)$. Next, the high practice category includes 19 respondents who went to primary school (24.1\%), 48 respondents who went to secondary school $(60.8 \%)$ and 12 respondents who went to college (15.2\%) as shown in (Fig. 3C). Only one respondent of the urban poor (100.0\%) falls under the low practice category. Next, six respondents of the urban poor were in the Medium Practice category (100.0\%). However, in the high practice category, there were 58 respondents from the urban poor 
(73.4\%), 16 respondents had middle income $(20.3 \%)$ and five respondents had high income $(6.3 \%)$ as shown in (Fig. 3D).
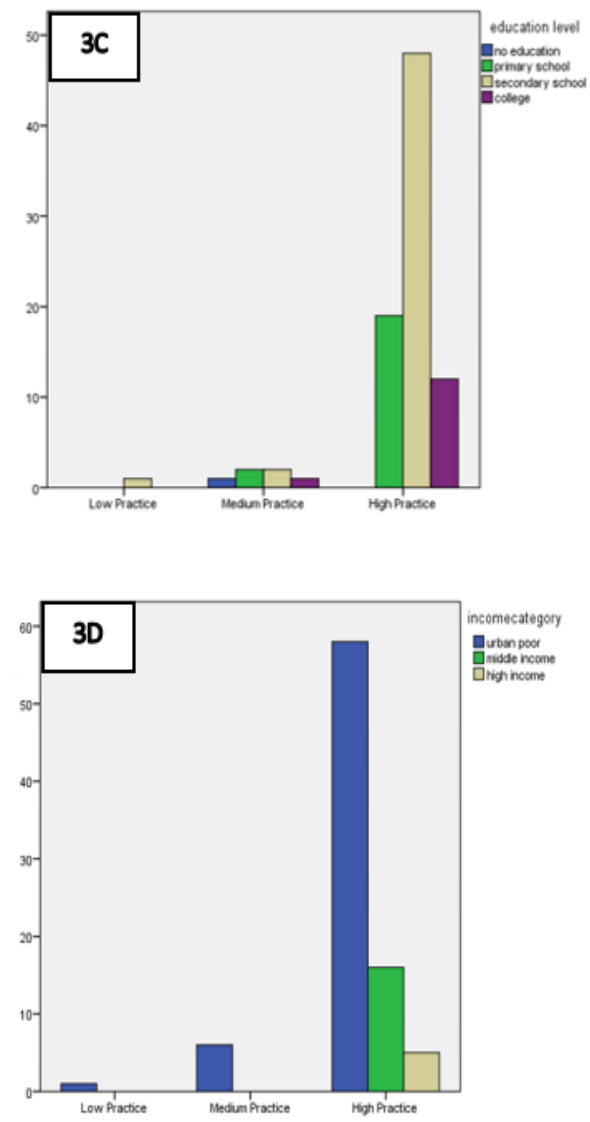

Fig 3C: Total Practice against Education Level Category,

Fig 3D: Total Practice against Income Category

This study findings showed high level of practice toward Dengue infection among respondents in Kampung Kepayang. $91.9 \%$ of respondents have good practice to prevent dengue infection. In contrast, in Balsam Mahdi Nasir Al-Zurfiet al.(2015), only $26.0 \%$ of Alam Shah Science School students in Cheras, Malaysia have good practice. This was probably due to the common practice the community have since they were living in the Kampung area (village) which has lot of mosquitoes. So, their practice was mainly to reduce the mosquito and not the dengue (Degallier et al., 2000). According to this study, there was little significance of relation between practice and sociodemographic factors except for education level. High education level was significantly related to high practice of prevention towards Dengue infection.

\section{CONCLUSION}

This study has shown that the community were aware about dengue infection (61.6\% in Knowledge, 51.9\% in Attitude and $91.9 \%$ in Practice). However, there was a bit lack of attitude regarding dengue infection and the impact of dengue outbreak in the community. This was because the percentage of participants that aware the risk of them getting infected by dengue was poor $(54.6 \%)$. More practical health education programmes should be organized. It will give more benefits and exposure which could increase the attitude of the community regarding dengue infection.

\section{ACKNOWLEDGEMENTS}

The authors thank the management, UniKL RCMP for allowing this project. Authors are also thankful to the respondents who filled in the survey which helps to carry out this project.

\section{Financial support and sponsorship: Nil.}

Conflict of Interests: There are no conflicts of interest.

\section{REFERENCES}

Abd Kadir SL, Yaakob H, Mohamed Zulkifli R. Potential antidengue medicinal plants: a review. J Nat Med. 2013;67(4):677-689.

Al-Zurfi BMN, Fuad MDF, Abdelqader MA, Baobaid MF, Elnajeh M, Ghazi HF et al. Knowledge, attitude and practice of dengue fever and heath education programme among students of Alam Shah science school, Cheras, Malaysia. Malaysian Journal of Public Health Medicine. 2015;15(2):69-74.

Degallier N, Vilarinhos PT, de Carvalho MS, Knox MB, Caetano J, Jr. People's knowledge and practice about dengue, its vectors, and control means in Brasilia (DF), Brazil: its relevance with entomological factors. J Am Mosq Control Assoc. 2000;16(2):114-23.

Guha-Sapir D, Schimmer B. Dengue fever: new paradigms for a changing epidemiology. Emerg Themes Epidemiol. 2005;2(1):1.

Khan E, Siddiqui J, Shakoor S, Mehraj V, Jamil B, Hasan R. Dengue outbreak in Karachi, Pakistan, 2006: experience at a tertiary care center. Trans R Soc Trop Med Hyg. 2007;101(11):1114-1119.

Koenraadt CJ, Tuiten W, Sithiprasasna R, Kijchalao U, Jones JW, Scott TW. Dengue knowledge and practices and their impact on Aedes aegypti populations in Kamphaeng Phet, Thailand. Am J Trop Med Hyg. 2006;74(4):692-700.

Messina JP, Brady OJ, Scott TW, Zou C, Pigott DM, Duda KA, et al. Global spread of dengue virus types: mapping the 70 year history. Trends in Microbiology. 2014;22(3):138-146.

Qadir MI, Abbas K, Tahir M, Irfan M, Raza Bukhari SF, Ahmed B, et al. Dengue fever: natural management. Pak J Pharm Sci. 2015;28(2):647-655.

Siqueira JB, Martelli CM, Maciel IJ, Oliveira RM, Ribeiro MG, Amorim FP, et al. Household survey of dengue infection in central Brazil: spatial point pattern analysis and risk factors assessment. Am J Trop Med Hyg. 2004;71(5):646-651.

Syed M, Saleem T, Syeda UR, Habib M, Zahid R, Bashir A, et al. Knowledge, attitudes and practices regarding dengue fever among adults of high and low socioeconomic groups. J Pak Med Assoc. 2010;60(3):243-247.

\section{How to cite this article:}

Firdous J, Mohamed A, Al-Amin M, Ihsan M, Imadi MF, Hakim MK, Afiq M, Muhamad N. Knowledge, Attitude and Practice Regarding Dengue Infection Among Ipoh Community, Malaysia. J App Pharm Sci, 2017; 7 (08): 099-103. 